\title{
An ailuravine rodent from the lower Eocene Cambay Formation at Vastan, western India, and its palaeobiogeographic implications
}

\author{
Rajendra S. Rana, Kishor Kumar, Gilles Escarguel, Ashok Sahni, Kenneth D. Rose, Thierry Smith, \\ Hukam Singh, and Lachham Singh
}

Acta Palaeontologica Polonica 53 (1), 2008: 1-14 doi:http://dx.doi.org/10.4202/app.2008.0101

\begin{abstract}
A new ailuravine rodent, Meldimys musak sp. nov. (Mammalia: Rodentia, Ischyromyidae), is recorded from the lower Eocene lignites of western India. It is the oldest record of Rodentia from India. M. musak is more derived than the earliest Eocene ailuravine Euromys cardosoi from Portugal and more generalized than late early Eocene E. inexpectatus and Ailuravus michauxi from France. Its dental morphology closely corresponds to the middle early Eocene species $M$. louisi, which lived about $52 \mathrm{Ma}$ in Western Europe. Meldimys was previously known only from Europe, and ailuravines were previously reported only from Europe and North America. Its occurrence in India allows the first direct correlation between the early Eocene land mammal horizons of Europe and India, and raises the possibility of a terrestrial faunal exchange between India and Eurasia close to the Palaeocene-Eocene transition.
\end{abstract}

Key words: Mammalia, Ailuravinae, Rodentia, palaeobiogeography, Eocene, India.

Rajendra S. Rana rs_rana_hnbgu@yahoo.com and Lachham Singh lachhamrawat@yahoo.co.in

, Department of Geology, HNB Garhwal University, Srinagar 246175 UA, India;

Kishor Kumar kumark@ wihg.res.in, Wadia Institute of Himalayan

Geology, 33 General Mahadeo Singh Road, Dehradun 248001 UA, India

(corresponding author); Gilles Escarguel gilles.escarguel@univ-lyon1.fr, UMR

CNRS 5125 Paléoenvironnements \& Paléobiosphčre, France; Université Lyon 1, Campus de la Doua, Bât. Géode F-69622 Villeurbanne Cedex, France; Ashok

Sahni ashok.sahni@gmail.com, Department of Geology, Panjab University,

Chandigarh 160 014, India; Kenneth D. Rose kdrose@ jhmi.edu,

Center for Functional Anatomy and Evolution, Johns Hopkins

University, School of Medicine, Baltimore MD 21205, USA; Thierry

Smith Thierry.Smith@naturalsciences.be, Department of Paleontology, Royal

Belgian Institute of Natural Sciences, B-1000 Brussels, Belgium; Hukam Singh hukams@gmail.com,

Birbal Sahni Institute of Palaeobotany, 53 University Road, Lucknow 226007 UP, India. 
This is an open-access article distributed under the terms of the Creative Commons

Attribution License (for details please see creativecommons.org), which permits unrestricted use, distribution, and reproduction in any medium, provided the original author and source are credited.

Faril Full text $(682.5 \mathrm{kB})$ 